\title{
各種床仕上材料を用いた暖房床の接触温熱感の評価方法に関する研究 A STUDY ON EVALUATION METHOD OF CONTACT THERMAL SENSATION FOR FLOOR HEATING WITH VARIOUS FLOORCOVERING
}

\author{
松井＼cjkstart勇*1, 湯 浅 昇*2, 沖 倉 優 代*3, 米久田 啓貴*4 \\ Isamu MATSUI, Noboru YUASA, Masayo OKIKURA \\ and Hiroki YONEKUTA
}

\begin{abstract}
The contact thermal sensation caused by foot or buttocks contacted with floor is one of the evaluation index for the floor heating. This paper deals with the evaluation method of the thermal sensation for the floor heating. The thermal sensation of testing floors with ten types of floorcovering and four floor temperatures was evaluated by bare foot,slippered foot and buttocks. The contacting surface temperature between an artificial foot and floor was measured. The test results are as follows; (1)The relation between floor temperature and thermal sensation is approximately on a straight line each floorcovering, and these lines crossed at foor temperature of $32{ }^{\circ} \mathrm{C}$ to $34{ }^{\circ} \mathrm{C}$. (2) The contacting surface temperature of artificial foot shows the same tendency as that of human foot. (3)The relation between floor temperature and contacting surface temperature is approximately on a straight line each floorcovering, and these lines crossed at floor temperature of $32{ }^{\circ} \mathrm{C}$ to $34{ }^{\circ} \mathrm{C}$. (4) The contacting surface temperature can estimate the thermal sensation of floor heating. (5) The comfortable range of sensation is $1.6^{\circ} \mathrm{C}$ to $3.2^{\circ} \mathrm{C}$ of contacting surface temperature.
\end{abstract}

Keywords: Floor, Floorcovering, Contact thermal sensation, Floor heating, Comfortable 床、床材料、接触温熱感、床暖房、快適性

\section{1.はじめに}

床暖房を使用した床（以後、暖房床と呼ぶ）は、床を温めて室内 温度を保持する暖房方式である。このため、足や慰部などの身体部 位の接触によって感ずる温熱感（以後、接触温熱感と呼ぶ）は暖房 床を評価するひとつの指鳔となる。暖房床の快適性は体感を中心に 研究されており、その基準は一般に床温度によって表されている。 しかし床の接触温熱感は床温度が同じでも床仕上材料の種類によっ ても相異する。このため、接触温熱感の観点から床の快適性を評価 する場合、床を構成している床仕上材料の影響を加味した評価方法 を確立する必要がある。これによって暖房床を設計する際、体感に 加えて接触温熱感を考慮した床温度及び床材料の選定が可能となる。 しかし現在、接触温熱感の観点から、種々の床仕上材料を用いて行 われた研究は少なく、また、暖房床の接触温熱感を評価する方法は 見当たらない。

本研究は、暖房床の床仕上材料が接触温熱感に及ぼす影響を明ら かにするとともに、暖房床の主として床仕上材料に起因する接触温 熱感の評価方法を提案することを目的としている。暖房床の接触温 熱感は、床から足や䌓部へ熱が供給され、これに伴って接触部の皮 膚温度が上昇し温かく感ずる。本研究は、この点に着目して試作し た模擬足を床に、接触させて測定した接触部温度変化を指呩として、
床仕上材料を種々変えた暖房床の接触温熱感を評価するとともに、 快適な接触温熱感の範囲を接触部温度変化によって提示したもので ある。

\section{2. 既往の研究}

床暖房の床温度の許容值については国内外で多くの研究がある。 国外では、Herrington, Lorenz $\mathrm{i}^{71}$ は2 $24^{\circ} \mathrm{C}$ 以下、Chrenk0" は病院で $26^{\circ} \mathrm{C}$ 、歩行で $25^{\circ} \mathrm{C}$ 、椅座位で $27^{\circ} \mathrm{C} 、 N e v i n s^{7)}$ は29. $4^{\circ} \mathrm{C}$ まで特に影響 なしとそれぞれ提案している。国内では、八木 ${ }^{8}$ は椅座位で $29 〜 30$ ${ }^{\circ} \mathrm{C}$ (空気温度 $20^{\circ} \mathrm{C}$ ) 、持田 $\left.{ }^{91}, 1{ }^{10}\right)$ は裧足で $30^{\circ} \mathrm{C}$ 以下、跳下で $32.33^{\circ} \mathrm{C}$ (空気温度 $20^{\circ} \mathrm{C}$ ) 、坊垣 ${ }^{11}$ ) は椅座位及び床座で $25 \sim 30^{\circ} \mathrm{C}$ （空気温 度 $18 \sim 20^{\circ} \mathrm{C}$ ) とし、快適温度の下限値として空気温度 $18^{\circ} \mathrm{C}$ で床温度 $25^{\circ} \mathrm{C}$ を提案している。これらの研究は体感を中心に研究している。 一般床の接触温熱感を評価する試験方法として、DIN52614 がある。これは鉄製の容器に $36^{\circ} \mathrm{C}$ の温水を入れて、床に接触させた ときの熱流量を試験する方法である。これは $36^{\circ} \mathrm{C}$ の温水を使用して いるため、床温度が高い暖房床の評価には適用し難い。本研究は、 暖房床の接触温熱感の観点から、床仕上材料の種類の影響及び袾足、 スリッパ及び慰部で接触した場合の影響を明らかにするとともに、 足の深部温度と皮膚温度を考慮した模擬足を試作し、これを暖房床

本論文は日本建築学会大会, 空気調和衛生工学会大会で報告したものをまとめたものである。

*1 日本大学生産工学部建築工学科 教授·工博

*2 日本大学生産工学部建築工学科 専任講師·工博

*3 沖倉一級建築士事務所 工修 (元日本大学大学院生産工学研究科 大学院生)

*4 日本大学生産工学部建築工学科 副手
Prof., Dept. of Architecture and Architectural Eng., College of Industrial Technology, Nihon Univ., Dr. Eng.

Lecturer, Dept. of Architecture and Architectural Eng., College of Industrial Technology, Nihon Univ., Dr. Eng. Okikura Sekkei, M. Eng.

Research Assoc., Dept. of Architecture and Architectural Eng., College of Industrial Technology, Nihon Univ. 


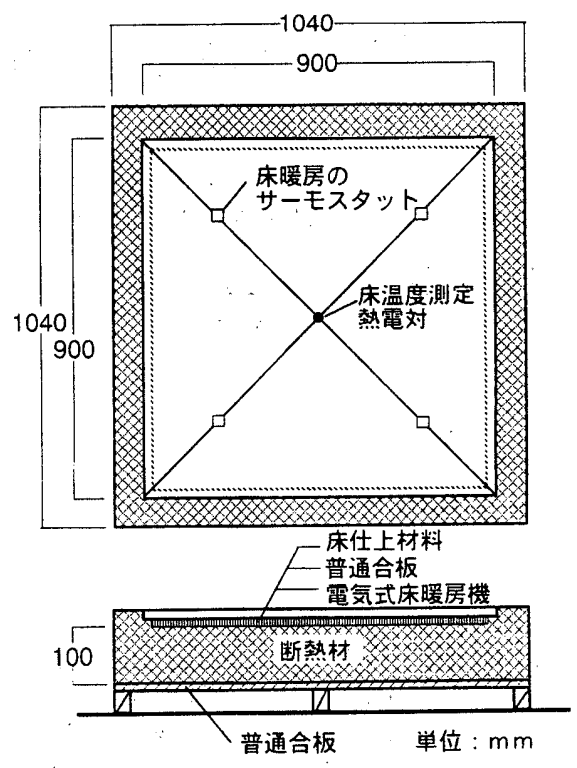

図-1 試験床の断面図

に接触させたときの接触部温度変化を用いて接触温熱感を評価する 方法を提案している。

\section{3. 本研究の篹围及び研究の方法}

本論文は、以下の範囲で研究を行った。

(1)暖房床の接触温熱感は、床との接触時間が長いほど温かく感ず る。このため暖房床の接触温熱感を評価する場合、短時間の接触で 評価した場合、長時間に比し高い床温度が要求される。そこで一般 の日常生活において床に接触している足や慰部などの身体部位を動 かすことなく床に接触している時間を10分間と考え、本研究ではこ の時間を接触温熱感の評価時間とした。この時間はDIN52614で規定 している時間と同じである。

(2) 床暖房の種類は電気式と温水式があるが、ここでは電気式の暖房 機を用いて試験した。

(3) 被験者は年齢20歳から23歳の男女学生とした。

本研究の方法は、以下の通りである。

(1) 床仕上材料及び床温度を変えた試験床を用いて、裸足、スリッパ を履いた場合及び臂部での接触温熱感を官能検查により評価する。

(2) 接触温熱感を評価するため; 模擬足を試作し、ヒトの足と模擬足 との接触部の温度変化及び熱流量を比較し、模擬足の性能を明らか にする。

(3)この模擬足を用いて、各種試験床の接触部温度変化を明らかにす る。

(4) 模擬足の接触部温度変化を用いて各種試験床の接触温熱感を評価 する。

\section{4. 床仕上材料及び床温度を变えた式験床の接触温熱感}

\section{1 実殹方法}

\subsection{1. 試耠床及び試殹室}

\section{(1) 試験床}

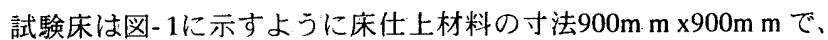


で、FM-1431型（温度コントローラ：of $\mathrm{f} 、 \mathrm{low}(80 \mathrm{~W}) \cdot \mathrm{mid}$ (140W) ・ hi gh (220W）) の及び FM-1731型（温度コントローラ : of $\mathrm{f}, 1$ ow $(50 \mathrm{~W}) \cdot \mathrm{mid}(105 \mathrm{~W}) \cdot$ hi gh (155W) ) の 2 機種を

\section{表-1 試験床の種類}

\begin{tabular}{|c|c|c|c|c|c|c|c|c|}
\hline \multirow{3}{*}{ 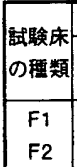 } & \multicolumn{6}{|c|}{ 床仕上材料の特性* 1} & \multirow{3}{*}{$\begin{array}{c}\text { 下地の } \\
\text { 厚さ } \\
\text { (m) }\end{array}$} & \multirow{3}{*}{\begin{tabular}{|c|}
$\begin{array}{c}\text { 横居楼 } \\
\text { の機理 }\end{array}$ \\
FH-1431 \\
FM-1431
\end{tabular}} \\
\hline & \multicolumn{2}{|c|}{ 床仕上村料の種類 } & \multirow{2}{*}{\begin{tabular}{|r|}
$\begin{array}{r}\text { 年さ } \\
(\min )\end{array}$ \\
7.0 \\
20.0 \\
\end{tabular}} & \multirow{2}{*}{\begin{tabular}{|c|}
$\begin{array}{c}\text { 比熹 } \\
(\mathrm{KJ} / \mathrm{kg} \mathrm{K})\end{array}$ \\
0.82 \\
1.20 \\
\end{tabular}} & \multirow{2}{*}{$\begin{array}{c}\begin{array}{c}\text { 比重 } \\
\left(\mathrm{kg} / \mathrm{m}^{\prime}\right)\end{array} \\
400 \\
20 \\
\end{array}$} & \multirow{2}{*}{\begin{tabular}{|c|}
$\begin{array}{c}\text { 熱伝遭军 } \\
(\mathrm{W} / \mathrm{nk})\end{array}$ \\
0.073 \\
0.041
\end{tabular}} & & \\
\hline & 能襍亲 & $\begin{array}{c}\text { カーベット } \\
\text { たたみ }\end{array}$ & & & & & & \\
\hline $\begin{array}{l}\text { F3 } \\
\text { F4 } \\
\text { F5 }\end{array}$ & $\begin{array}{l}\text { フラス } \\
\text { チック } \\
\text { 絮 }\end{array}$ & $\mid \begin{array}{c}\text { フォームボリスチレン } \\
\text { 塩化ビニルタイイ } \\
\text { 化ヒニルシート }\end{array}$ & $\begin{array}{l}7.0 \\
2.0 \\
3.0\end{array}$ & $\begin{array}{l}1.2 \\
0.47 \\
0.28\end{array}$ & $\begin{array}{l}20 \\
1500 \\
450\end{array}$ & $\begin{array}{l}0.041 \\
0.19 \\
0.078\end{array}$ & $\begin{array}{l}\text { なし } \\
12.0 \\
12.0\end{array}$ & $\begin{array}{l}F M-1731 \\
F N-1731 \\
F N-1731\end{array}$ \\
\hline $\begin{array}{l}\text { F6 } \\
\text { F7 }\end{array}$ & 木留采 & $\begin{array}{l}\text { フローリンタ } \\
\text { コルクタイル }\end{array}$ & $\begin{array}{c}15.0 \\
4.5\end{array}$ & $\begin{array}{l}\text { 1. } 30 \\
1.30\end{array}$ & $\begin{array}{l}550 \\
500\end{array}$ & $\begin{array}{l}0.150 \\
0.14\end{array}$ & $\begin{array}{l}\text { なし } \\
2.0\end{array}$ & $\begin{array}{l}\text { FU-1731 } \\
\text { FH-1431 }\end{array}$ \\
\hline $\begin{array}{l}\text { F8 } \\
\text { F9 } \\
\text { F10 }\end{array}$ & 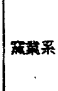 & 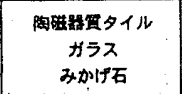 & $\begin{array}{c}7.0 \\
10.0 \\
5.0\end{array}$ & $\begin{array}{l}0.84 \\
0.77 \\
0.84\end{array}$ & $\begin{array}{l}2400 \\
2540 \\
2800\end{array}$ & $\begin{array}{l}1.300 \\
0.78 \\
3.500\end{array}$ & $\begin{array}{l}2.0 \\
2.0 \\
2.0\end{array}$ & $\mid \begin{array}{l}\text { FM-1431 } \\
\text { FM-1731 } \\
\text { FM-1731 }\end{array}$ \\
\hline
\end{tabular}

*1: 林料の熱物性値は日本建喿学会編設計资料集成及びカタログによる。

表-2 裸足およびスリッパの官能試験における試験床と床温度の組合せ

\begin{tabular}{|c|c|c|c|c|c|c|c|c|}
\hline \multirow{2}{*}{ 試呀床の桶類 } & \multicolumn{8}{|c|}{ 被渎者グループ別の床 温 度 $\left.{ }^{(}{ }^{\circ} \mathrm{C}\right)$} \\
\hline & A & B & C & D & $\mathrm{E}$ & F. & G: & $\mathrm{H}$ \\
\hline F 1 & 20.1 & 32.5 & 34.0 & 36.9 & - & - & - & - \\
\hline F 2 & - & - & - & - & 19.8 & 25.2 & 27.1 & 28.0 \\
\hline F 3 & - & - & - & - & 30.5 & 21.4 & 28. 4 & 30. 2 \\
\hline F 4 & - & - & - & - & 33.3 & 38.6 & 21.8 & 27.4 \\
\hline F 5 & 36.6 & 21.0 & 30.8 & 32.5 & - & - & - & - \\
\hline F 6 & 29.8 & 38.1 & 27: 1 & 19.7 & - & - & - & - \\
\hline F 7 & 20.1 & 33. 0 & 37. 1 & 38.5 & - & - & - & - \\
\hline F 8 & - & - & - & - & 31.5 & 37.4 & $45: 3$ & 19.8 \\
\hline F 9 & - & - & - & - & 21.5 & 25.8 & 34.4 & 37.5 \\
\hline F 10 & 27.5 & 36.4 & 43.2 & 20.8 & - & - & - & - \\
\hline 裸足の被験者数 & 9 & 7 & 8 & 9 & 8 & 9 & 7 & 8 \\
\hline  & 8 & 8 & 8 & 9 & 9 & 8 & 10 & 8 \\
\hline
\end{tabular}

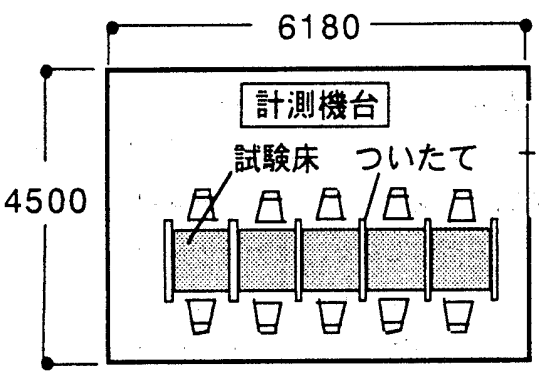

図-2 試験室の平面図 単位: $m m$

用いた。試験床の種類を表-1に示す。床仕上材料は熱特性の異なる 材料をできるだけ幅広く用いたいため、フォームポリスチレンから みかげ石まで10種類としたが、材料の厚さはそれぞれ異なっているる。 ここで使用した、たたみは厚さ20mmのオームポリスチレンを畕床 とし、これに畳表を張ったものである。また下地の合板については、 床表面温度の差異を明確にするため、下地の厚さや有無を定めた。 また、カーペットおよびたたみの試験床は、他の試験床と同じ床暖 房機(FM-1473)を用いると、他の試験床より床温度が低くなること が予想されたため、定格消費電力の大きい床暖房機(FM-1431)を用 いた。さらに、試験において、床温度の範囲を広くするために、够 磁器質タイルの試験床についは定格消費電力の大きい床暖房機( FM -1431)を用いて、他の試験床より高い床温度が得られるようにした。 下地を有する仕上材料は、両面接着テープを用いて下地合板に接着 し、この合板を床暖房機に両面接着テープで接着した。下地合板を 有しない材料は両面接着テープを用いて床暖房機に直接接着した。 このように、試験床の仕様が若干異なるため、本論文においては試 
表-3 㙰部の官能試験における 試験床と床温度の組合せ

\begin{tabular}{|c|c|c|c|c|c|c|}
\hline \multirow{2}{*}{$\begin{array}{l}\text { 試験床 } \\
\text { の種類 }\end{array}$} & \multicolumn{6}{|c|}{ 被験者グループ別の床温度（ㄷ） } \\
\hline & A & B & C & D & $E$ & $F$ \\
\hline F1. & - & 21.7 & - & 21.9 & - & 34.8 \\
\hline F2 & 21.7 & - & 26. 2 & - & 27.6 & - \\
\hline F3 & 32.9 & - & 21.3 & - & 29.8 & - \\
\hline $\mathrm{F} 4$ & 28.8 & - & 34.4 & - & 22.8 & - \\
\hline F5 & - & 33. 7 & - & 21.5 & - & 27.6 \\
\hline F6 & - & 29.1 & - & 33. 8 & - & 21.9 \\
\hline F7 & - & 39.5 & - & 21.0 & - & 32.7 \\
\hline F8 & 22.0 & - & 28.8 & - & 39. 7 & - \\
\hline F9 & 36.3 & - & 21.5 & - & 29. 6 & - \\
\hline F10 & - & 21.5 & - & 29. 5 & - & 37. 2 \\
\hline $\begin{array}{c}\text { 盟部の } \\
\text { 被鉺者数 }\end{array}$ & \multicolumn{6}{|c|}{10} \\
\hline
\end{tabular}

験床の記号F1〜F10を用いて考察している。

試験床の床温度は、試験床の中央に張り付けた熱電対によって管 理した。床の温度分布は足や壂部が接触する範囲ではほほ同じ温度 であった。床温度は、床暖房機に表示してある温度コントローラ （of f, low, m i d及びhi gh）によって変えた。このため床温度は表-2 に示すように、試験床の種類によってそれぞれ異なっている。 ただし、床温度 $20.8 \pm 1{ }^{\circ} \mathrm{C}$ の場合は床暖房機に通電しない場合（off） である。

\section{（2）試験室}

試験室は図-2に示す恒温室で、温度 $20 \pm 1{ }^{\circ} \mathrm{C}$ 、湿度約50\%とした。 試験室には、同時に5種類の試験条件で官能検查が行えるように5台 の試験床を設置した。

\section{1.2 官能検查方法}

\section{（1）被験者}

被験者は、年齢20２3 歳の男女学生である。

(2) 官能検査の姿勢

官能検查の姿勢は椅子に腰掛けて裸足で床に触れた場合（以下裸 足という）、椅子に腰掛けてスリッパを履いた場合（以下スリッパ という）及びあぐらで座って臀部が直接床に接触した場合（以下腎 部という）について行った。被験者にはこれらの姿勢で10分間でき るだき動かないように指示した。あぐらで座る場合は被験者に同一 のジャージのズボンを着用させた。被験者の着衣量は0.7 0.8cloで ある。

\section{（3）被験者への試験床の提示}

官能検査に当たって、試験床と床温度の組み合わせが多いため、 裸足及びスリッパの場合は、表-2に示すように試験床（10種類）と


各グループの被験者数は7〜10名で、これらの被験者はそれぞれ異な っている。慰部の場合は、表-3に示すように試験床（10種類）と床 温度（3水準）の組合せを $\mathrm{A} \sim \mathrm{F}$ までの6グループに分け、10名の同 じ被験者がこれらの組合せを全て評価した。

\section{（4）接触温熱感の評価}

被験者は、それぞれの姿勢で椅子に腰掛けて30分間試験室で安静 にした後、裸足及びスリッパの場合は椅子に腰掛けた状態で、試験 床の中央部に足を10分間接触させ、10分後の足裏で感じた接触温熱 感を評価した。层部の場合は試験床の上に10分間座り、眤部で感じ た接触温熱感を評価した。被験者の疲労を考慮して、ひとつの試験 床の評価が終了した後、10分間休憩した。これを5種類の試駼床につ
表-5 官能検查の分散分析結果

\begin{tabular}{|c|c|c|c|c|c|c|c|}
\hline \multirow{2}{*}{$\begin{array}{l}\text { 被験者 } \\
\text { グループ }\end{array}$} & \multirow{2}{*}{ 要因 } & \multicolumn{2}{|c|}{ 裸足の結果 } & \multicolumn{2}{|c|}{ スリッパの結果 } & \multicolumn{2}{|c|}{ 繁部の結果 } \\
\hline & & 不偏分散 & 分散比 & 不偏分散 & 分散比 & 不偏分散 & 分散比 \\
\hline A & $\begin{array}{c}\text { 試験床間 } \\
\text { 被験者間 } \\
\text { 諾差 } \\
\end{array}$ & $\begin{array}{l}14.14 \\
1.56 \\
0.32\end{array}$ & $\begin{array}{c}\text { 44. } 28 * \neq \\
\text { 4. } 87 \star * \\
-\end{array}$ & $\begin{array}{l}6.02 \\
0.86 \\
0.34\end{array}$ & $\begin{array}{c}\text { 17. } 76 \neq * \\
\text { 2. } 56 * * \\
-\end{array}$ & $\begin{array}{l}30.70 \\
2.02 \\
0.86\end{array}$ & $\begin{array}{c}35.70 \neq \neq \\
\text { 2. } 35 \neq \neq \\
-\end{array}$ \\
\hline B & $\begin{array}{c}\text { 試験床間 } \\
\text { 被験者間 } \\
\text { 誤差 }\end{array}$ & $\begin{array}{l}11.19 \\
0.78 \\
0.81\end{array}$ & $\begin{array}{c}13.80 \approx * \\
0.96 \\
-\end{array}$ & $\begin{array}{l}4.48 \\
1.65 \\
0.32\end{array}$ & $\begin{array}{c}14.97 * * \\
5.12 * * \\
-\end{array}$ & $\begin{array}{l}36.40 \\
0.98 \\
0.35\end{array}$ & $\begin{array}{c}103.50 * * \\
2.78 * * \\
-\end{array}$ \\
\hline c & $\begin{array}{c}\text { 試験床間 } \\
\text { 被験者間 } \\
\text { 誤差 }\end{array}$ & $\begin{array}{l}18.40 \\
2.40 \\
0.41\end{array}$ & $\begin{array}{c}44.41 * * \\
5.78 * * \\
-\end{array}$ & $\begin{array}{l}5.79 \\
3.26 \\
0.30\end{array}$ & $\begin{array}{c}\text { 19. } 18 * * \\
\text { 10. } 79 \neq * \\
-\end{array}$ & $\begin{array}{l}17.40 \\
0.95 \\
0.30\end{array}$ & $\begin{array}{c}58.46 * \# \\
3.20 * * \\
-\end{array}$ \\
\hline D & $\begin{array}{c}\text { 試験床間 } \\
\text { 被験者間 } \\
\text { 誤差 }\end{array}$ & $\begin{array}{l}16.86 \\
2.22 \\
0.74\end{array}$ & $\begin{array}{c}22.68 * * \\
2.99 * \\
-\end{array}$ & $\begin{array}{l}8.50 \\
2.76 \\
0.64\end{array}$ & $\begin{array}{c}\text { 13. } 33 \neq \neq \\
4.32 \neq \neq \\
-\end{array}$ & $\begin{array}{l}19.00 \\
1.07 \\
0.45\end{array}$ & $\begin{array}{c}42.10 * * \\
2.37 * \\
-\end{array}$ \\
\hline$E$ & $\begin{array}{c}\text { 試験床間 } \\
\text { 被験者間 } \\
\text { 誤差 }\end{array}$ & $\begin{array}{l}15.59 \\
8.91 \\
0.57\end{array}$ & $\begin{array}{c}27.19 * * \\
15.54 * * \\
-\end{array}$ & $\begin{array}{l}3.52 \\
1.76 \\
0.43\end{array}$ & $\begin{array}{c}8.10 \neq * \\
4.05 \neq \# \\
-\end{array}$ & $\begin{array}{l}21.90 \\
1.04 \\
0.36\end{array}$ & $\begin{array}{c}60.22 \neq * \\
2.86 \neq \\
- \\
\end{array}$ \\
\hline $\mathrm{F}$ & $\begin{array}{c}\text { 試験床間 } \\
\text { 被験者間 } \\
\text { 誤差 }\end{array}$ & $\begin{array}{l}19.94 \\
9.97 \\
0.49\end{array}$ & $\begin{array}{c}40.34 \neq \neq \\
20.17 \neq \neq \\
-\end{array}$ & $\begin{array}{l}3.84 \\
2.19 \\
0.61 \\
\end{array}$ & $\begin{array}{c}6.30 * * \\
3.60 \neq * \\
- \\
\end{array}$ & $\begin{array}{l}20.20 \\
0.89 \\
0.32\end{array}$ & $\begin{array}{c}63.42 * * \\
2.76 * \\
-\end{array}$ \\
\hline G & $\begin{array}{c}\text { 試験床間 } \\
\text { 被験者間 } \\
\text { 誤差 } \\
\end{array}$ & $\begin{array}{l}33.79 \\
2.25 \\
0.57\end{array}$ & $\begin{array}{c}59.37 * * \\
3.95 * * \\
-\end{array}$ & $\begin{array}{c}11.82 \\
1.18 \\
0.63\end{array}$ & $\begin{array}{c}18.90 \approx * \\
1.88 \\
-\end{array}$ & - & - \\
\hline$H$ & $\begin{array}{c}\text { 試験床間 } \\
\text { 被験者間 } \\
\text { 誤差 }\end{array}$ & $\begin{array}{l}20.35 \\
0.80 \\
0.41\end{array}$ & $\begin{array}{c}49.98 * * \\
1.96 \\
-\end{array}$ & $\begin{array}{l}3.63 \\
2.05 \\
0.34\end{array}$ & $\begin{array}{c}10.68 * * \\
6.05 * * \\
-\end{array}$ & - & - \\
\hline
\end{tabular}



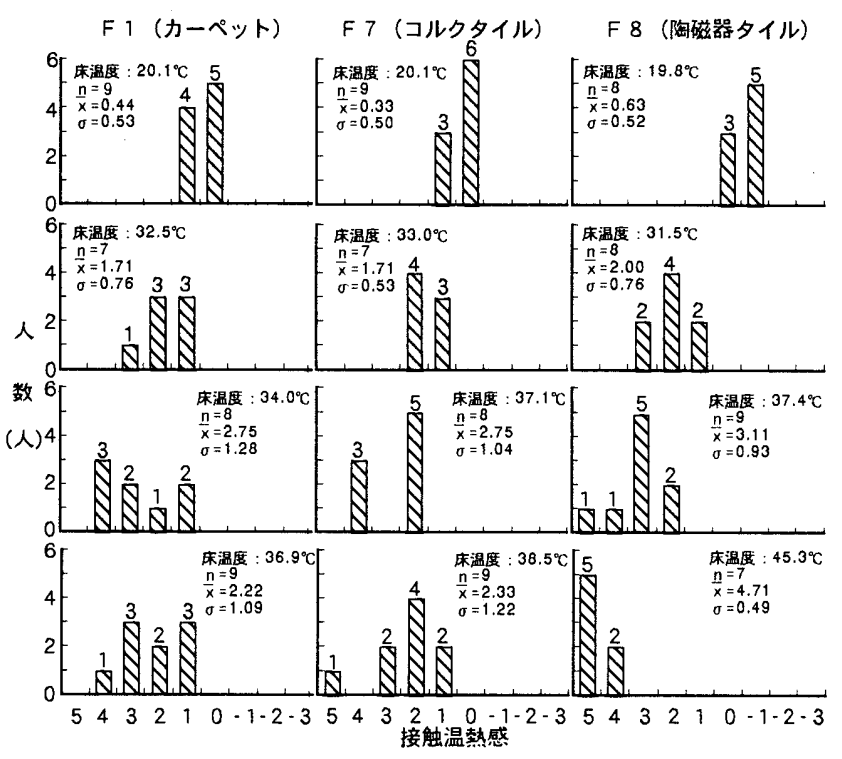

図-3 接触温熱感の評価のばらつき

いて繰り返し行った。検査開始から終了までの所要時間は休覣を含 めて120分間である。

接触温熱感の評価は表-4に示す 9 段階とした。官能検査に用いる 評価は、「どちらでもない」を境として対称になるのが一般的であ る。空調設備基準委員会温冷小委員会活動報告「温冷感に関する調 査方法（昭和51年度版）」によれば、温冷感について「熱い」「暖 かい」「涼しい」「寒い」の用語が提案されている。これらの用語 は体感として捉えたもので、接触にともなう身体局部の温熱感を表 現したものではない。そこで、本研究では、「暑い」を「熱い」に、 「暖かい」を「温かい」「寒い」を「冷たいと」と置き換えて使用 した。また「涼しい」に変わる接触温熱感の表現用語がないため、 本研究ではこれに代わる表現を用いることはしなかった。接触温熱 感は被験者の平均値で示した。 


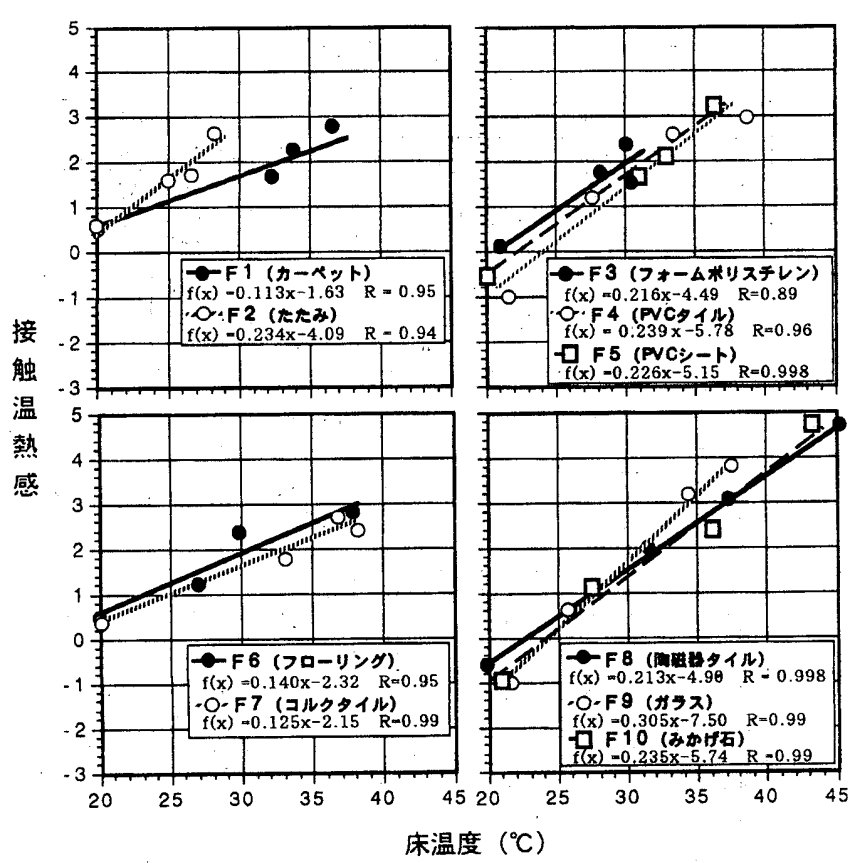

図-4 各種試験床の床温度と接触温熱感の関係

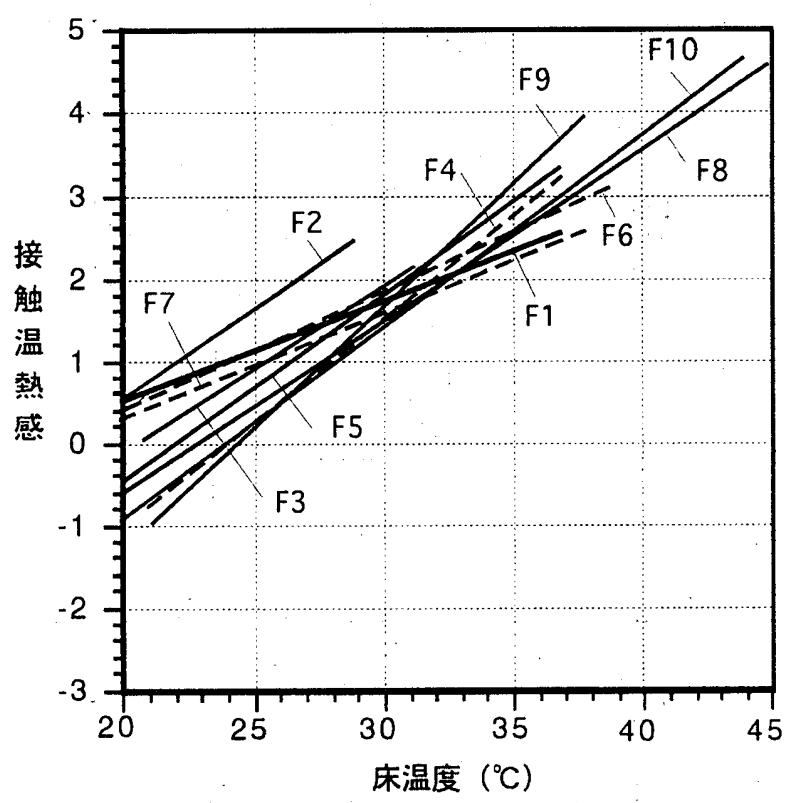

図-5 床温度と接触温熱感との関係（平均線）

\section{2. 結果及び考察}

（1）官能検査の分散分析結果

官能検査の分散分析結果を表-5に示す。いずれの検査条件でも試 験床間では危険率 $1 \%$ で有意差が認められ、また被験者間でも危険率 1 5\%で有意差が認めら执るものもある。しかし、試験床間の分散 比が被験者間の分散比よりも大きくなっており、今回の官能検査結 果は試験床の差を評価していると判断できる。

（2）接触温熱感の評価のばらつき

F1（カーペット）、F7（コルクタイル）及びF8（陶磁器タイル） の場合について、各床温度について接触温熱感の評価のばらつきを 図-3に例示する。床温度が約 $20 \pm 1^{\circ} \mathrm{C}$ （温度コントローラ: of f ）にお ける接触温熱感の評価の標準偏差はいずれの材料も0. 5 程度であるが、 床温度が31. 5 38. $5^{\circ} \mathrm{C}$ における標準偏差は0. 53〜1.28程度と大きく なる。床温度が $45^{\circ} \mathrm{C}$ （陶磁器タイルの場合）になると、標準偏差は

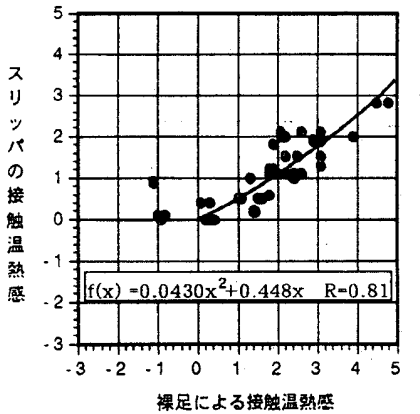

図-6 裸足とスリッパの 接触温熱感の比較

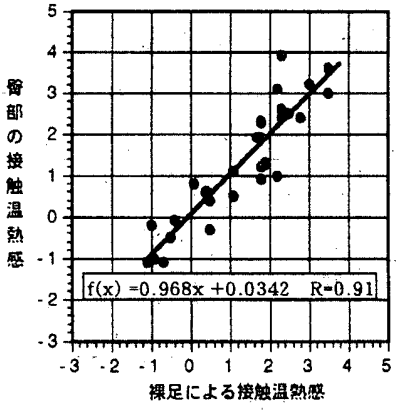

図-7裸足と腤部の 接触温熱感の比較
これより小さくなっている。このように、床温度が低い場合（温度 コントローラ: of f） あるいは床温度が非常に高い場合の評価のばら つきは小さくなっている。

(3) 各種試験床の床温度と接触温熱感の関係

各種試験床の床温度と接触温熱感の関係を図-4に示す。いずれの 試験床も床温度が高くなるに従って、接触温熱感は温かい方へ移行 している。床温度と接触温熱感の関係はいずれの試験床もほぼ直線 を示している。

これらの直線をまとめた結果を図-5に示す。試験床F 2（たたみ） 及びF 3 (フォームポリスチレン) を除くと、これらの直線は $32^{\circ} \mathrm{C}$ $\sim 34^{\circ} \mathrm{C}$ 付近で交差している。F 2及びF 3はいずれもフォームポリス チレンを用いた材料であり、保温性が高いために接触していると、 床の温度の割には温かく感じるようである。この2つの試験床を除 くと、床温度が低い場合は、䇺業系材料は他の材料に比して冷たく 感じ、床温度が高い場合は、温かく感じている。これは、床仕上材 料の熱的特性によるもので、一般に言われているように、熱伝導率 の大きい材料は小さい材料に比して、高温では床から足へ熱が多く 流れるため足裏の温度が高くなり、より温かく感じ、常温で徒か ら床へ熱が多く奪われるため足の温度が低くなり、より冷たく感ず ることを示している。しかし、床温度が $32^{\circ} \mathrm{C} \sim 34^{\circ} \mathrm{C}$ 範囲において は、F 2及びF 3の試験床を除くと、いずれの床仕上材料を用いた試 験床でも接触温熱感の評価の差異は小さくなっている。これは、こ の温度範囲に10分間接触していると、足裏の温度と床の温度がほほ 同じになり、床から足へ（床温度が足裹の温度より高い場合）ある いは足から床へ（床温度が足裏の温度より低い場合）流れる熱量が 材料によって差異が小さくなるためである。この温度範囲は接触時 間が長くなると高くなると予想される。

(4)裸足・スリッパ・层部の接触温熱感の比較

裸足とスリッパの接触温熱感の比較を図-6に示す。スリッパを履 いた場合、裸足で冷たいと感ずる範囲では「どちらでもない」と評 価しているが、床温度が高くなり裸足で「温かい」、熱い」と感ず る範囲では、スリッパによって床からの熱が遮断されるため、袾足、 に比べて床温度による温かさの効果は少なくなる。

裸足と剧部の接触温熱感の比較を図-7に示す。ジャージを着用し て座った慰部の接触温熱感は裸足とほぼ同程度に評洒されている。

\section{5. 模㩧足}

接触温熱感は、材料に接触したときの皮膚と材料との間で熱の授

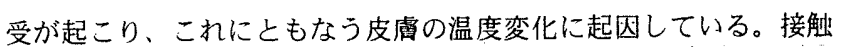
温熱感を評価する物性値として、材料の比熱 $\mathrm{c}$, 密度 $\rho$ 、熱伝導率 


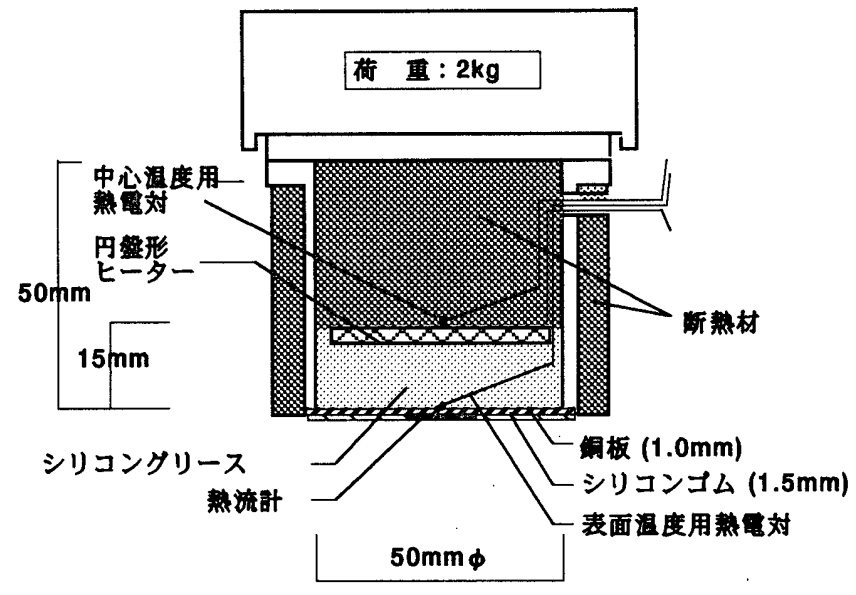

図-8 模擬足の断面図

$\lambda$ を用いて計算により求めた熱浸透率 $\sqrt{\mathrm{C \rho} \rho}\left(\mathrm{Wh} / \mathrm{m}^{2} \mathrm{~h}{ }^{1 / 2}{ }^{\circ} \mathrm{C}\right)$ が 用いられている。熱浸透率は、温度が異なる2つの半無限個体が接 触したときの接触面を流㧈る熱量と接触部の温度の関係から理論的 に求められた物性值である。しかし、実際の床仕上材料は厚さも有 限で、また表面の凹凸や表面の薄い塗膜を有する場合などがり、こ れらの要因によって接触温熱感が異なるため材料の比熱、密度、熱 伝導率だけでは接触温熱感を評価する物理量として用いることはで きない。そこで、温めた模擬足を床に直接接触させて、その接触部 の熱移動に伴う接触部温度変化を測定することは、これらの影響を 測定できるため、接触温熱感を評価する物性値として有効である。 このような測定方法については、D IN 52614の方法があるが、これ は $36^{\circ} \mathrm{C}$ の温水を鉄製の容器に入れ、これを床に接触させ、接触面に 設置した熱流量計によって、熱流量を測定するもので、暖房床のよ うに床温度が高い場合には適用しがたい。

そこで足が床に接触したときの接触部温度をヒトの足に変わって 測定する模擬足を試作した。

\section{1 模提足の原理及び捵造}

\section{（1）模擬足の原理}

皮膚が物の表面に触れたとき、接触部の皮膚温度は変化する。皮 慮の温度変化によってヒトは温かい・冷たいと感ずる ${ }^{171}$ ，181，19?。

模擬足はこの現象をヒトの足に代わって再現するため試作したも のである。試作に当たって、ヒトの足の接触部温度とほぼ等しくな るように以下の点を考慮した。

(1)皮膚が物の表面に接触したとき、皮膚から人体内部（あるいは人 体内部から皮䖉）へ流れる熱は伝導によるものである。このため模 擬足の内部に人体と同程度の熱的物性值を有するシリコングリース を詰めた。

(2)人体の深部温度は皮膚表面温度より高い。このため、模擬足の内 部にヒーターを設けて、内部温度を表面温度より高くした。

(3)人体は皮膚から空気中へ常に熱が放散し、皮膚温度は安定してい る。模擬足を空中に懪したとき、模擬足の表面は人体の皮膚温度と 等しくなるように、また表面からの放熱量は人体の皮膚からの放散 熱量と等しくなるように内部七ーターの位置を定めた。

\section{(2) 模擬足の構造}

試作した模擬足を図-8に示す。

(1)模擬足は内径 $50 \mathrm{~m} \mathrm{~m}$ 高さ $50 \mathrm{~m} \mathrm{~m}$ 肉厚 $5 \mathrm{~m} \mathrm{~m}$ のプラスチック製容器 で、シリコングリースを詰めたものである。床との接触面は、厚さ
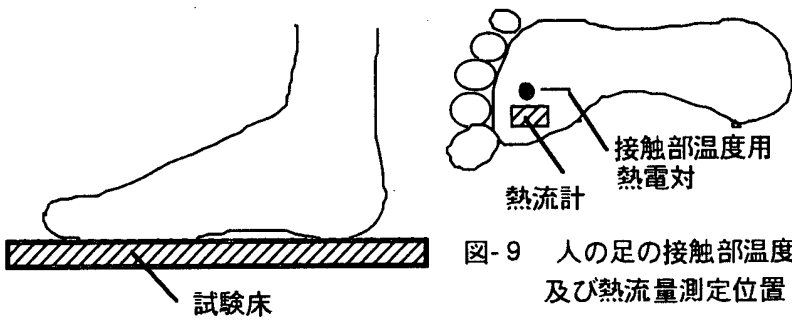

図-9人の足の接触部温度 及び熱流量測定位置

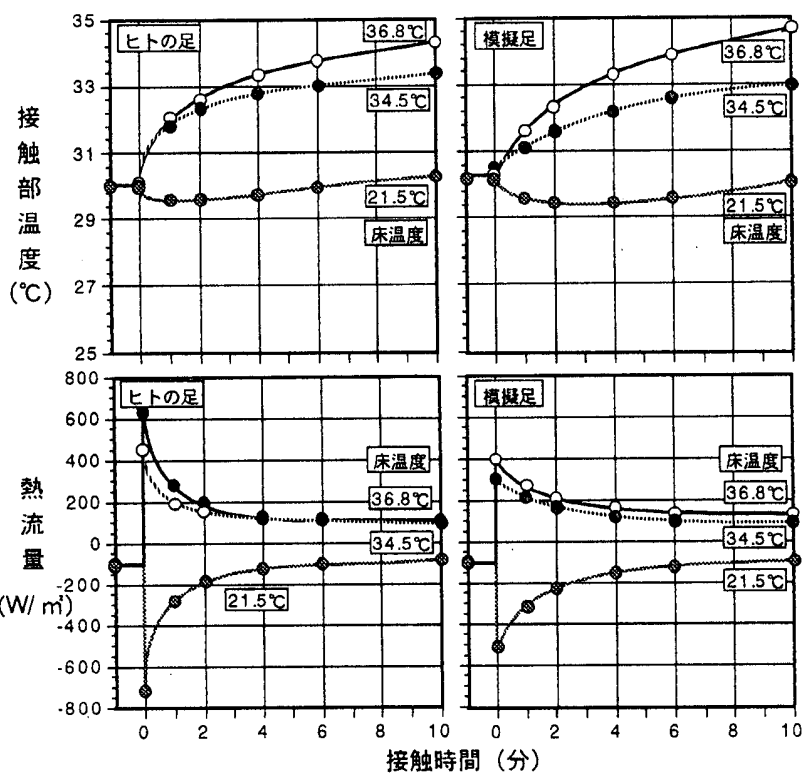

図-10 ヒトの足と模擬足の接触部温度および熱流量の経時変化

$1 \mathrm{~m} \mathrm{~m}$ 銅板に厚さ $1.5 \mathrm{~m} \mathrm{~m}$ のシリコンゴムを張り付けたものである。 (2)模擬足は接触面に対して平行熱流とするため、円盤形のヒーター

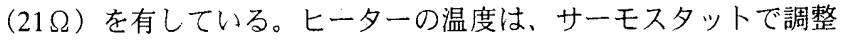
している。ヒーターは、内部温度が $33^{\circ} \mathrm{C}$ (足の深部温度に相当）に 設定したとき、模擬足の表面温度が $30^{\circ} \mathrm{C}$ （皮膚温度に相当）になる ように銅板から $15 \mathrm{~m} \mathrm{~m}$ 離れた位置に設置した。

(3)内部は皮膚と同程度の熱伝導率を有するシリコングリース（ $\mathrm{S}$ 社 製 K S609、比熱c: $0.46 \mathrm{w} \mathrm{h} / \mathrm{kg} \mathrm{K}$ 比重量 $\rho: 2.53 \mathrm{~kg} / \mathrm{m}^{3}$ 、熱伝 導率入: $0.628 \mathrm{~W} / \mathrm{m} \mathrm{K}$ が詰めてある。

(4)プラスチック製容器の周囲は厚さ $7 \mathrm{~m} \mathrm{~m}$ の断熱材で断熱してある。 これは、模擬足周囲の環境温度によって、模擬足の中心部温度及び 測定中の接触部温度変化が影響されないために断熱したものである。 (5)模擬足の中心部温度は、ヒ一夕部に張り付けてある熱電対（JIS C $1602 " \mathrm{~T} "$ 線径 $0.32 \mathrm{~m} \mathrm{~m}$ 熱電対は以後同じものを使用）により 測定する。表面温度は銅板に張り付けてある熱電対により測定する。 熱流量は銅板に張り付けた熱流量計（E 社製 C N-9）によって測定 する。ただしこの熱流量は参考までに取り付けたものである。

(6)模擬足の上部に $2 \mathrm{~kg}$ の重りを載荷する。この荷重は、重りを $0.5 \mathrm{~kg}$ 〜 $5 \mathrm{~kg}$ まで変えて試験した結果、 $2 \mathrm{~kg}$ を越えると試験結果に及ぼす荷 重の影響はほとんど認められなかったので、重りは2Kgとした。

\section{2 模㩧足の接触部温度変化の测定方法}

模擬足は、接触面を $20^{\circ} \mathrm{C}$ の空気中に曝した状態で、中心部温度が $33^{\circ} \mathrm{C}$ 、表面温度が $30^{\circ} \mathrm{C}$ 一定になったとき床に接触させる。このとき 模擬足の表面温度および熱流量を10分間記録する。

10分後の接触部温度変化は（1）式によって求める。 


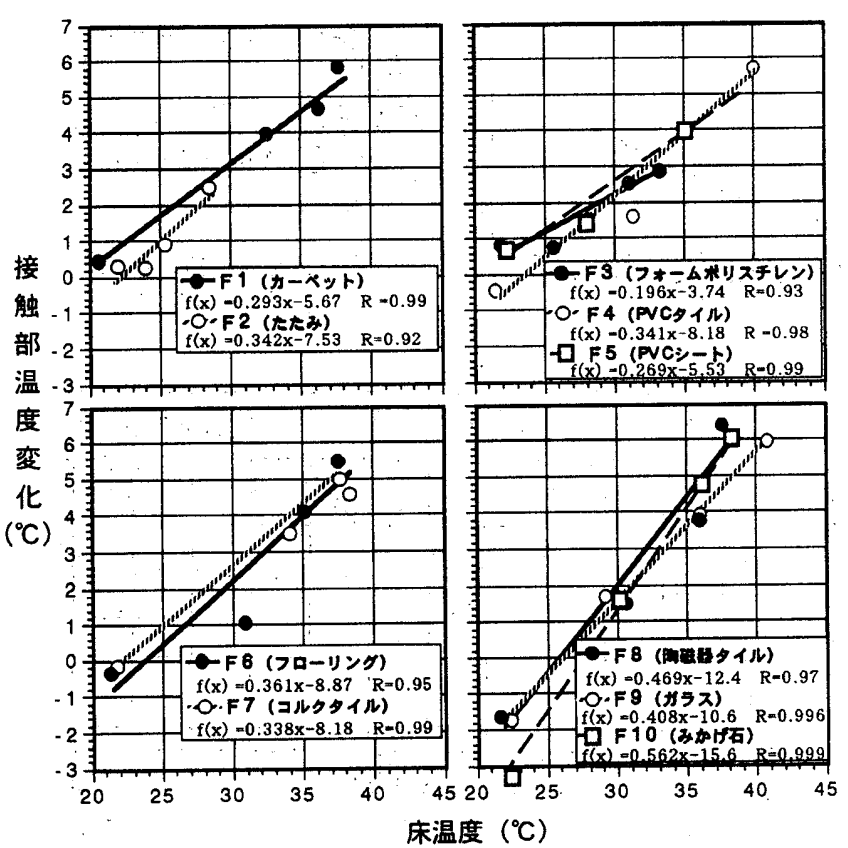

图-11 各種試験床の床温度と接触部温度変化との関係

試験は3回行い、その平均値で示す。

$c T_{10}=T_{10}-T_{0} \ldots \ldots$ (1)

ここに、 $\mathrm{cT}_{10}$ ：接触部温度変化 $\left({ }^{\circ} \mathrm{C}\right)$

$\mathrm{T}_{10}: 10$ 分後の表面温度 $\left({ }^{\circ} \mathrm{C}\right)$

$\mathrm{T}_{0}{ }^{\prime}:$ 接触前の表面温度 $\left({ }^{\circ} \mathrm{C}\right)$

\section{6. 模搌足とヒトの足の接触部の温度変化及び熱流量の比較 \\ 6.1 试唤方法}

模擬足とヒトの足の接触部の温度及び熱流量を比較するため、図 -9に示すように、ヒトの足裏に熱電対及び熱流計をあらかじめ張り 付计て、床に10分間接触させて測定した。試駼に用いた試駼床はフ ローリングを張り付けた試験床（F6）である。床温度は21.5 $5^{\circ} \mathrm{C}($ 温度

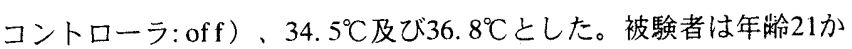
ら23歳の男女学生 3 名で被足で椅座とした。試駼結果は被験者の場 合 3 人の平均值で示した。模擬足の場合は前項5.2に準じて試験した。

\section{2 結果及ひ考察}

ヒトの足および模擬足の接触部の温度および熱流量の経時変化を 図-10に示す。熱流量は足から熱が放散している場合をマイナス、足 が受熱している場合をプラスと符号を付した。接触前のヒトの足及 び模擬足の表面温度は約 $30^{\circ} \mathrm{C}$ 、熱流量は約- $100 \mathrm{~W} / \mathrm{m}^{2}$ を示している。 床温度が34. $5^{\circ} \mathrm{C} 、 36.8^{\circ} \mathrm{C}$.の床に接触すると、模擬足及びヒトの足い ずれも、接触部温度は時間経過に伴って、また床温度が高くなるに 従って上昇している。床温度が $21.5^{\circ} \mathrm{C}$ の場合、両者とも接触部温度 は接触直後降下しているが、その後時間経過に伴って上昇している。 これは接触後足から供給された熱によって足と床との間の温度が上 昇するためである。熱流量は、接触直後に最大值を示し、その後、 時間経過に伴って滅少している。

このように、模擬足の接能部温度及び熱流量の経時変化は上卜の 足と同じ傾向を示している。

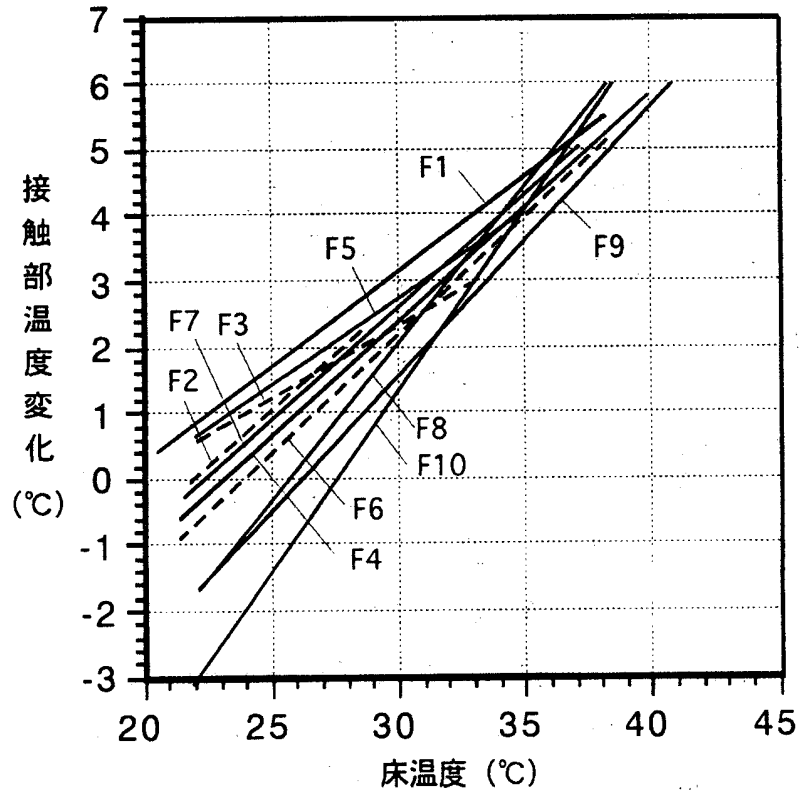

図-12 床温度と接触部温度变化との関係（平均線）

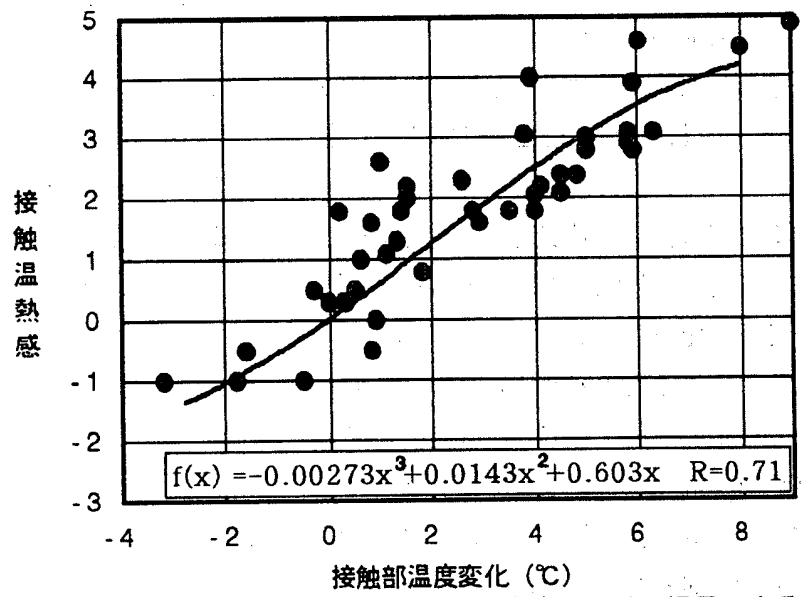

図-13 接触部温度変化と接触温熱感との関係（裸足による）

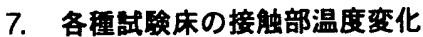

\section{1 嗔酸方法}

（1）試験床及び試験室

試験床及び試験室は前項4.1.1に準ずる。試験した時期が官能検査 と異なっているため、この試駼の床温度は官能検查時の床温度と異 なっている。

（2）模擬足による接触部温度変化の試験方法

これは前項5.2に準ずる。

\section{2 結果及ひ考察}

各種試験床の床温度と接触部温度変化との関倸を図-11に示す。床 温度が高くなるに従って、接触部温度変化は直線的に大きくなって いる。これらの直線の傾きは試験床の仕上材料の種類によって相異 している。これらの直線をまとめて図-12に示す。F2（たたみ）を 除くと、これらの直線の傾きはほほ熱伝導率の大きさの順に大きく なっている。またこれらの直線はF1、F2を除くと床温度 $32^{\circ} \mathrm{C} \sim 34^{\circ} \mathrm{C}$ で交差している。この交差している床温度は図-5の床温度とほぼ同 様である。しかし図-12に比し図-5は直線の傾きがばらついている。 これは図-5は被験者による接触温熱感の評価値によるもので図-12 は模擬足による接触部温度変化であるため、前者に比し後者の方が 機械的な測定值であるためばらつきが小さいものと考えられる。 


\section{8. 接触部温度変化と接触温熱感との関係}

接触部温度変化と接触温熱感との関係を図-13に示す。模擬足によ る接触部温度変化を試験した時期が官能検査を行った時期と異なる ため、床温度は官能検查時と異なっている。そこで、官能検査時の 床温度に対する接触部温度変化を図-11を用いて補正を行って作図し たものである。両者の関係は、接触部温度変化に対する接触温熱感 のばらつきが評点でほぼ士1の範囲にあるが、接触部温度変化が「0」 で、接触温熱感の評点「0」（どちらでもない）を通るなめらかな 曲線で示すことができる。この結果より、接触部温度変化が「 $0^{\circ} \mathrm{C} 」$ で接触温熱感は「どちらでもない」、「1.6」で「やや温かい」、

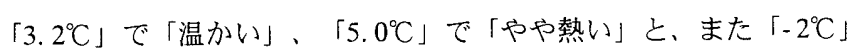
で「やや冷たい」と評価される。床暖房の接触温熱感の快適さは、 一般床に比して積極的な温かさが求められ、「どちらでもない」の 評価では満足しない。そこで、本研究では「温かい（評点2）」と 「やや温かい（評点1）」を暖房床の接触温熱感の快適さと考えて、 この範囲を接触部温度変化で示すと $1.6^{\circ} \mathrm{C} \sim 3.2^{\circ} \mathrm{C}$ となる暖房床の 床温度及び床材料を設計するときは暖房床の仕様に忘じて模擬足に より接触部温度変化を測定して、図-13および図-12を用いて快適な 床温度を得ることができる。例えば快適な接触温熱感を得るために は図-12を用いて、接触部温度変化 $1.6 \sim 3.2^{\circ} \mathrm{C}$ のさき $\mathrm{F} 6$ （フロー リング）の床温度を求めると、 $28^{\circ} \mathrm{C} \sim 33^{\circ} \mathrm{C}$ とな。同様にF1（力 一ベット)の床温度は $24^{\circ} \mathrm{C} \sim 30^{\circ} \mathrm{C}$ となる。

\section{9. むすひ}

本研究の結果を以下に要約する。

（1）床温度と接触温熱感との関倸は、いずれの試験床においてもほ ぼ直線を示し、直線の傾きは鶷業系材料を用いた試験床が最も大き く、またこれらの直線は床温度 $32^{\circ} \mathrm{C} \sim 34^{\circ} \mathrm{C}$ で交差する。

（2）試作した模擬足を床に接触させたときの接触部の温度及び熱流 量の経時変化はヒトの足の場合とほぼ同様の傾向を示した。

(3) 床温度と接触部温度変化との関係は、いずれの試験床において もほぼ直線を示し、直線の傾きは窯業系材料を用いた試験床が最も 大きく、またこれらの直線は接触温熱感と同様に、床温度 $32^{\circ} \mathrm{C} \sim 34$ ${ }^{\circ} \mathrm{C}$ で交差する。

（4）接触部温度変化によって暖房床の接触温熱感を評価することが できる。

（5）暖房床の接触温熱感の快適な範囲は、接触部温度変化で $1.6^{\circ} \mathrm{C}$ 〜3. $2^{\circ} \mathrm{C}$ である。

なお本研究の一部は空気調和・衛生工学会「床暖房のアメニティ 評価に関する研究委員会」の委員として参加したときに行ったもの で、この機会を与えていただきました委員長，故貝塚正光氏（元明 治大学教授）並びに委員各位に対し表心より感謝の意を表します。
また実験を行うに際し、床暖房を提供いだ゙きました元日本床暖房 工業会会長の鈒持忠男氏、床材料を提供いただきました東リ株式会 社高岡秀樹氏に対し心から感謝の意を表します。更に官能検査の被 験者としてご協力いただきました多くの学生に心より感謝の意を表 します。

\section{考文献}

1）松井勇、床暖房時の床に接触させた模擬足の接触温度及び熱流量、 日本建築学会大会学術講演梗概集、pp. 749-750、1990.10

2）松井勇、模擬足による床の接触温熱感の評価方法 その 2 、空気 調和・衛生工学会学術講演会講演論文集、pp. 405 408、1992. 10

3）松井勇、湯浅昇、沖倉優代、床の接触温熱感に関する研究 その 1 七トの足と模擬足の温度変化及び熱流量の比較、日本建筑学会大会 学術講演梗概集、pp. 639-640、1993.9

4）沖倉優代、松井勇、湯浅昇、暖房床の接触温熱感に関する研究、

日本建築学会大会学術講演梗概集、pp. 641-642、1993.9

5）松井勇、沖倉優代、模擬足による床の接触温熱感の評価方法 そ の3ヒトの模擬足の比較、空気調和 - 衛生工学会学術講演会講演論 文集、pp. 13〜16、1993.10

6）松井勇、湯浅昇、沖倉優代、床の接触温熱感に関する研究 その 2袾足とスリッパ及び座位の接触温熱感の比較、日本建筑学会大会学 術講演梗概集、pp. 661-662、1995.8

7）（社）空気調和・衛生工学会「床暖房のアメニティ評価に関する 研究報告畫」1990.6、1991.5、1992.6

8）八木一彰、坊垣和明、江口和雄、体感気候に関する研究第I X報、

日本建築学会大会学術講演梗概集、pp. 579 580、1978.9

9）土門謙太郎、持田徹、広瀬喜則、床暖房の適温に関する実験的研 究、空気調和 - 衛生工学会北海道支部学術講演論文集、pp. 36 37、 1981. 1

10）広瀬喜則、持田徹、土門謙太郎、床暖房時の足部温感と床面温 の関係、空気調和・衛生工学会北海道支部学術講演論文集、pp. 38 39. 1981.1

11）坊垣和明、床弾道の体感降下に関する実験的研究II、空気調和

・衛生工学会学術講演会講演論文集、pp. 201～204、1986.10

12）田中正敏、床暖房時の高齢者の仰臥位、座位による温熱反応、 空気調和・衛生工学会学術講演会講演論文集、pp. 401 404、1992. 10

13) D IN 52614 T esting of Thermal Insulations Determition of Heat D issipation of Floors

14）空調設備基準委員会温冷感小委員会活動報告「温例感に関する 調査方法（昭和51年度版）」

15）上園正義、水容器式模擬足による床材の接触温冷感評価、第13 回日本熱物性シンポジウム講演論文集、pp. 364〜366、1992. 9.

16）大野剛義、岩本静男、暖房床の接触温感の数值予測 その1 模 擬足と接例面の熱的特性に関する数値予測、空気調和・衛生工学会 学術講演会講演論文集、pp. 1293〜1296、1994.10

17）棚沢一郎、生物之伝熱、生産研究、Vol. 23, N o. 5, pp. 171 177, 1971.5

18）棚沢一郎、勝田直、生物体における熱的物性值の測定 第2 報、 生産研究、Vol . 24, N o. 10, pp. 26〜29, 1972. 10

19）棚沢一郎、小沢宏一、人間の局部温度感覚に関する伝熱学的研 究、生産研究、Vol. 31, N o. 6, pp. 552 554, 1976.6

20）松井勇、笠井芳夫、仕上材の感触に関する研究 (温冷感触 その2）、日本建築学会論文報告集、第294号、pp. 1 12, 1980.8 